\title{
CYCLODEXTRINES AS FUNCTIONAL AGENTS FOR DECONTAMINATION OF THE SKIN CONTAMINATED BY NERVE AGENTS
}

\author{
Jiř́ Cabal ${ }^{1}$, Kamil Kuča ${ }^{1}$, Lucie Ševelová-Bartošová ${ }^{1}$, Vlastimil Dohnal ${ }^{2}$ \\ Purkyně Medical Military Academy, Hradec Králové, Czech Republic: Department of Toxicology ${ }^{1}$; Masaryk University, \\ Faculty of Science, Brno, Czech Republic: Department of Analytic Chemistry ${ }^{2}$

\begin{abstract}
Summary: Three decontamination solutions of $\beta$-cyclodextrines were prepared. Their abilities to decontamine rat skin contamined with nerve agent soman were tested. Decontamination efficacy of the tested cyclodextrine solutions was compared with the same decontamination means but without the cyclodextrines. The efficacy of tested decontaminants was evaluated by the assessment of the $\mathrm{ID}_{50}$ values. Two decontamination prescriptions with cyclodextrines (tetraborate buffer and tetraborate buffer with acetone) do not show significantly better decontamination efficacies in comparison with prescriptions without cyclodextrines. Only in case of aqueous solution of 2-aminoethanol the addition of $\beta$-cyclodextrine resulted in significant increase (32\%) in decontamination efficacy.
\end{abstract}

Key words: Cyclodextrine; Nerve agents; Decontamination; In vivo; Soman; Skin; Acetylcholinesterase

\section{Introduction}

Cyclodextrines [CDs] are cyclic oligosacharides formed by a number of glucose units linked with alpha-(1-4) glycosidic bonds. There are three known basic structures that differ only in the number of units. The alpha-cyclodextrine $[\alpha-C D]$, of six units, beta-cyclodextrine [ $\beta-C D]$ of seven units and the gama-cyclodextrine $[\chi-\mathrm{CD}]$. All of them have as a common feature the existence of a hydrophobic central cavity surrounded by a hydrophilic ring formed by hydroxyl groups (7).

These seminatural artificial receptors can bind a variety of organic, inorganic and biological guest molecules inside their apolar cavities in aqueous solution to form host-guest complexes or supramolecular systems (17).

Therefore, this fascinating property enables them to be successfully used as drug carriers $(10,16)$, separation reagents $(6,25)$, enzyme mimics $(2,18)$ and catalysts of the chemical reactions (20). Relatively little of this work has been concerned with the hydrolysis of the organophosphorus compounds $(1,3)$.

Organophosphorus compounds used at the present time as pesticides [paraoxon] or as chemical warfare agents [sarin, soman, cyclosarin, tabun] belong among irreversible inhibitors of the enzyme acetylcholinesterase [AChE; EC 3.1.1.7] (13,15). AChE plays a key role in the physiological function of the cholinergic nervous system and, therefore, its inhibition is life-endangering (14).

The relatively unsatisfactory antidotal treatment available for acute poisonings with organophosphates has prompted the study of prophylaxis possibilities that allow survival of organisms exposed to organophosphates (4).

There is considerable interest in methods for the decontamination of the skin after contamination with these agents $(8,11)$. Several methods of nerve agents decontamination are based on the sorption into the porous materials [currently used decontamination mean in the Czech Army, called DESPRACH] $(21)$, on the micelar catalysis $(5,12)$ or on the cyclodextrine host-guest interactions $(3,22)$, as mentioned above.

In this study, we have prepared decontamination solutions of beta-cyclodextrines and tested their ability to decontamine rat skin contamined with nerve agent soman. Decontamination efficacy of the tested cyclodextrine solutions was compared with the same decontamination means but without the cyclodextrines.

\section{Material and Methods}

\section{Chemicals}

Beta-cyclodextrine $[\beta-C D]$ was obtained from the Military Technical Institute [VU 070, Brno, Czech Republic]. Solubility in the water solutions, purity and chemical identity of the $C D$ were checked as follows. Solubility in the water solutions was checked at the temperature $25^{\circ} \mathrm{C}$ in distilled water. Determined range of solubility agrees with the data described earlier by Steitlim (19) - for beta-CD 1,8 g / $100 \mathrm{ml}$. Solubilities in the solution of natrium hydroxide $[\mathrm{pH}=9]$ and in the solution of natrium hydroxide [pH =9] mixtured with $0,1 \mathrm{M} \mathrm{KCl}$ was tested too. Observed range of 
solubility does not differ from the values measured for distilled water.

Purity and chemical identity of the CD was tested using thin layer chromatography on the Merck glass plates [ $n \mathrm{BuOH}:$ EtOH: $\left.\mathrm{H}_{2} \mathrm{O}-4: 3: 3\right]$ and using IR spectroscopy [specromether Philips PU 9706]. Other impurities were not observed in the sample. Organophosphate soman [Fig. 1] [O-pinacolylmethylfluorophosphonate] was obtained from the Military facility [VOZ 072, Zemianské Kostolany, Slovak Republic] in 95\% purity.

All other chemicals used in this work were commercial products of Merck or Sigma-Aldrich.<smiles>CC(OP(C)(=O)F)C(C)(C)C</smiles>

Fig. 1: Chemical structure of the soman.

Tab. 1: Composition of the tested decontamination solutions.

\begin{tabular}{|c|l|l|}
\hline Number & $\begin{array}{l}\text { Name of the decon- } \\
\text { tamination solution }\end{array}$ & Composition* \\
\hline 1 & Tetraborate buffer & $32.4 \mathrm{ml}$ of 0.13 \\
& $\mathrm{pH}=9$ & $\mathrm{M}$ natrium tetraborate \\
& & $16.7 \mathrm{ml}$ of $0.10 \mathrm{M} \mathrm{HCl}$ \\
& & $50.9 \mathrm{ml}$ distilled water \\
\hline 2 & Tetraborate buffer & $32.4 \mathrm{ml}$ of 0.13 \\
& with the addition & $\mathrm{M}$ natrium tetraborate \\
& of the $\beta$-CD & $16.7 \mathrm{ml}$ of $0.10 \mathrm{M} \mathrm{HCl}$ \\
& & $50.9 \mathrm{ml}$ distilled water \\
& & $1.70 \mathrm{~g}$-CD \\
\hline 3 & Tetraborate buffer & $32.4 \mathrm{ml}$ of 0.13 \\
& with acetone & $\mathrm{M} \mathrm{natrium} \mathrm{tetraborate}$ \\
& & $16.7 \mathrm{ml}$ of $0.10 \mathrm{M} \mathrm{HCl}$ \\
& & $23.1 \mathrm{ml}$ distilled water \\
& & $27.8 \mathrm{ml}$ acetone \\
\hline 4 & Tetraborate buffer & $32.4 \mathrm{ml}$ of 0.13 \\
& and acetone with & $\mathrm{M} \mathrm{natrium} \mathrm{tetraborate}$ \\
& the addition of the & $16.7 \mathrm{ml}$ of $0.10 \mathrm{M} \mathrm{HCl}$ \\
& $\beta-C D$ & $23.1 \mathrm{ml}$ distilled water \\
& & $27.8 \mathrm{ml}$ aceton \\
& & $1.70 \mathrm{~g} \beta$-CD \\
\hline 5 & water solution & $30 \mathrm{ml}$ 2-aminoethanol \\
& of 2-aminoethanol & $70 \mathrm{ml}$ distilled water \\
\hline 6 & water solution of & $30 \mathrm{ml} 2$-aminoethanol \\
& $2-$ aminoethanol with & $70 \mathrm{ml}$ distilled water \\
& the addition of the & $1.70 \mathrm{~g} \beta$-CD \\
& $\beta-C D$ & \\
\hline
\end{tabular}

*composition for $100 \mathrm{ml}$ of the final solution

Animals

Male white albino Wistar rats weighing 180-200 g were purchased from Velaz Praha [Czech Republic]. They were kept in an air-conditioned room $\left[22 \pm 1{ }^{\circ} \mathrm{C}\right.$ and $50 \pm 10 \%$ relative humidity] with lights from 07.00 to 19.00 and were allowed free access to standard food and tap water ad libitum. The rats were divided into groups of five animals each $[n=5]$. Before the experiment they were shaved on their dorsal part [ $3 \times 5 \mathrm{~cm}$ ]. Experiments were performed under the supervision of the Ethics Committee of Medical Faculty of Charles University and Purkyně Military Medical Academy in Hradec Králové, Czech Republic.

\section{Decontamination solutions}

There were prepared six kinds of decontamination solutions - tetraborate buffer $\mathrm{pH}=9$, tetraborate buffer with the addition of the $\beta-C D$, tetraborate buffer with acetone, tetraborate buffer with acetone and with the addition of the $\beta$-CD, water solution of 2-aminoethanol and finally water solution of 2-aminoethanol with the addition of the $\beta$-CD. Composition of all tested decontamination solutions is described in the Table 1.

\section{In vivo experiments}

The efficacy of the cyclodextrine solutions to decontaminate soman contaminated rat skin was determined using modified in vivo decontamination test (4). To determine the decontaminating efficacy of the tested solutions, the rats were poisoned percutaneously [p.c.] with the appropriate dose of organophosphate soman and then they were decontaminated using CDs solutions. The control group were rats contaminated with soman, but decontamination was not performed. The decontamination with CD solutions was started 2 min following p.c. poisoning. The decontamination solution was used at a dose of $1.6 \mathrm{ml}$ per animal and it was spread on the contaminated skin area using defined tampons [weight $327 \pm 23.5 \mathrm{mg}$ ] within $30 \mathrm{~s}$.

\section{Data analysis}

The $\mathrm{LD}_{50}$ values and their $95 \%$ confidence limits were calculated by probit analysis of deaths occurring within 24 hours after p.c. administration of soman at five different doses with five animals per dose (23). Efficacies of decontamination solutions were compared using $\mathrm{ID}_{50}$ values [Protective ratio]. Index $\mathrm{ID}_{50}$ was calculated from the values of $\mathrm{LD}_{50}$ measured with the decontamination, and $\mathrm{LD}_{50}$ without the decontamination.

$$
\mathrm{ID}_{50}=\mathrm{LD}_{50 \text { p.c. decontaminated }} / \mathrm{LD}_{50 \text { p.c. non-decontaminated }}
$$

Just as the index $\mathrm{ID}_{50}$ is high, the decontamination solution is potent.

\section{Results}

Contamination of the skin of experimental animals with soman was performed as described above. The decontamination action with one of different six decontamination prescriptions tested in our study, was started 2 minutes 
after application of toxic organophosphorus compound. The efficacy of tested decontaminants was evaluated by the assessment of the $\mathrm{ID}_{50}$ values using Weil's test (23). Results for all decontamination receptures are presented in Table 2.

Tab. 2: Decontamination efficacy of solutions.

\begin{tabular}{|c|l|c|}
\hline Number & $\begin{array}{l}\text { Name of the decontamination } \\
\text { solution }\end{array}$ & $\begin{array}{c}\mathrm{ID}_{50} \text { p.c. } \\
(\text { rat })\end{array}$ \\
\hline 1 & Tetraborate buffer $\mathrm{pH}=9$ & 6.1 \\
\hline 2 & Tetraborate buffer with $\beta$-CD & 5.9 \\
\hline 3 & Tetraborate buffer with acetone & 6.7 \\
\hline 4 & $\begin{array}{l}\text { Tetraborate buffer with acetone } \\
\text { and } \beta-C D\end{array}$ & 7.4 \\
\hline 5 & Aqueous solution of 2-aminoethanol & 12.6 \\
\hline 6 & $\begin{array}{l}\text { Aqueous solution of 2-aminoethanol } \\
\text { with } \beta-C D\end{array}$ & 16.7 \\
\hline
\end{tabular}

All the decontaminants tested show the value of $\mathrm{ID}_{50}$ higher than 1 . Whence it follows that all the prescriptions for decontamination solutions effect as decontaminants of the skin contaminated with soman. When solutions 1 and 2 are compared, it is clear that the decontamination efficacy is decreased by CD addition. On the contrary, in case of tetraborate buffer with acetone [3, 4], the addition of $\mathrm{CD}$ resulted in $\mathrm{ID}_{50}$ increase. Acetone addition into the decontamination solution only slightly increases the $\mathrm{ID}_{50}$ value. Nevertheless the substitution of tetraborate buffers [solutions 1-4] for 2-aminoethanol solution [solutions 5, 6] significantly enhances the decontamination efficacy of the appropriate solutions. Even in case of solution 6, the value of decontamination efficacy $\mathrm{ID}_{50}$ achieves 16.7. From results presented in Table 2 it can be concluded that the most effective decontaminant is the prescription consisting of aqueous solution of 2-aminoethanol and $\beta-C D[6]$.

\section{Discussion}

Well-timed skin decontamination is the crucial step after percutaneous poisoning with chemical warfare agents (4). Several modalities of skin decontamination can be recently applied as described above $(5,12,21,22)$. Cyclodextrines can serve as suitable decontaminants after skin contamination with nerve agents due to their ability to form host-guest complexes (17).

Our in vivo results show that addition of $\beta-C D$ into the solution of tetraborate buffer and tetraborate buffer with acetone does not cause significant increase in decontamination efficacy. Only in case of aqueous solution of 2-aminoethanol, the addition of $\beta-C D$ resulted in significant increase [32\%] in decontamination efficacy. Ineffectiveness of tetraborate decontaminants has two reasons. At first, neat soman applied on the skin has considerably higher affinity to mixture of lipophile and hydrophile medium represented by skin than to aqueous medium of decontaminating solution (24). In consequence soman does not reach the CD molecules in short time and sufficient amount and thus the process of decontamination does not run at desirable rate. Slow diffusion from the solid surface into the solution is the direct action of the whole process, instead of the rapid chemical reaction. Secondly, during our experiment it was found that the animal skin is within 1 to 2 minutes after decontamination action completely dry and thus the decontaminating reaction is stopped, because the suitable medium for reaction running is not available and soman with respect to its low volatility proceeds further with penetrating into the skin (24).

The addition of acetone into the decotaminant solution should avoid problems with soman insolubility but it resulted only in slight increase in ID50 value. Rapid evaporation of solvents from the surface, even potentiated by acetone adding, probably caused lower efficacy than we expected. Therefore acetone was replaced by 2-aminoethanol with much lower volatility in comparison with acetone (9). In addition with regard to 2-aminoethanol, structure there is no presumption of competition with soman for CD cavity occupation.

In conclusion, decontamination prescriptions with $\mathrm{CD}$ $[2,4]$ do not show significantly better decontamination efficacies in comparison with prescriptions without CD. In case of decontaminants with 2-aminoethanol [6], the satisfactory decontamination efficacies were achieved.

\section{Acknowledgement}

The authors wish to thank to Mrs. Martina Hrabinová and Mrs. Eva Vodáková for her skilful assistance. This work was supported by the grant of Ministry of defense, No. OBVLAJEP20032.

\section{References}

1. Barr L, Easton CJ, Lee K, Lincoln SF, Simpson JS. Metallocyclodextrin catalysts for hydrolysis of phosphate triesters. Tetrahedron Lett 2002;43: 7797-800

2. Breslow R, Dong SD. Biomimetic reactions catalyzed by cyclodextrins and their derivatives. Chem Rev 1998;98:1997-2012.

3. Cabal J. Hydrolytic reactions of methylfluorophosphonates with cyclodextrins. Collect Czech Chem Commun 1995;60:1162-9.

4. Cabal J, Kassa J, Severa J. A comparison of the decontamination efficacy of foam-making blends based on cationic and nonionic tensides against organophosphorus compounds determined in vitro and in vivo. Hum Exp Toxicol 2003;22:507-14.

5. Cibulka R, Hampl F, Kotoučová H, Mazáč J, Liška F. Quaternary pyridinium ketoximes - new efficient micellar hydrolytic catalysts. Collect Czech Chem Commun 2000;65:227-42

6. Flurer ChL, Lin LA, Satzger RD, Wolnik KA. Determination of ephedrine compounds in nutritional supplements by cyclodextrin-modified capillary electrophoresis. J Chrom B 1995;669:133-9.

7. Grigera JR, Caffarena ER, de Rosa S. Computer simulation of the cyclodextrin-phenylalanine complex. Carboh Res 1998;310:253-9.

8. Gordon RK, Feaster SR, Russel AJ et al. Organophosphate skin decontamination using immobilized enzymes. Chem Biol Interact 1999;119-20:463-70.

9. Gordon AJ, Ford RA. The chemist's companion - A handbook of practical data, techniques and references. Wiley: New York, 1972.

10. Ishizuka Y, Fujiwara M, Kanazawa K, Nemoto T, Fujita K, Nakanishi H. Threedimensional structure of the inclusion complex between phloridzin and $\beta$-cyclodextrin. Carboh Res 2002;337:1737-43.

11. Knezevic DL, Tadic V, Cetkovic S. The efficacy of different decontaminants in rats and pigs percutaneously poisoned with organophosphates. Vet Hum Toxicol 1993;35:403-5. 
12. Kotoučová H, Mazáč J, Cibulka R, Hampl F, Liška F. Unusual Course of the $p$ Nitrophenyl Phosphate Esters Cleavage by 3-Hydroxyiminoalkylpyridinium Salts in Micellar Solutions. Chem Lett 1998;27:649-50.

13. Kuča K, Bielavský J, Cabal J, Kassa J. Synthesis of a new reactivator of tabun-inhibited acetylcholinesterase. Bioorg Med Chem. Lett 2003;13:3545-7.

14. Kuča K, Kassa J. A comparison of the ability of a new bispyridinium oxime1-(4-hydroxyiminomethylpyridinium)-4-(4-carbamoylpyridinium)butane dibromide and currently used oximes to reactivate nerve agent-inhibited rat brain acetylcholinesterase by in vitro methods. J Enzyme Inhib Med Chem 2003;18:529-35.

15. Kuča K, Patočka J, Cabal J. Reactivation of organophosphate inhibited acetylcholinesterase activity by $\alpha, \omega$-bis-(4-hydroxyiminomethylpyridinium)alkanes in vitro J Appl Biomed 2003;4:207-11.

16. Lai S, Locci E, Piras A, Porcedda S, Lai A, Marongiu B. Imazalil-cyclomaltoheptaose ( $\beta$-cyclodextrin) inclusion complex: preparation by supercritical carbon dioxide and ${ }^{13} \mathrm{C}$ CPMAS and ${ }^{1} \mathrm{H}$ NMR characterization. Carboh Res 2003 338:2227-32.

17. Liu Y, Li L, Zhang HI, Liang P, Wang H. Inclusion complexation behavior of dyestuff guest molecules by a bridged bis(cyclomaltoheptaose)[bis $\beta$-cyclodextrin)] with a pyromellitic acid diamide tether. Carboh Res 2003;338:1751-7.

18. Rizzarelli E, Vecchio G. Metal-complexes of functionalized cyclodextrins as en zyme models and chiral receptors. Coord Chem Rev 1999;188:343-64.

19. Steitli J. Cyclodextrins and their Inclusion complexes. 1 ed. Budapest 1982

20. Szejtli L, Osa T. Comprehensive Supramolecular Chemistry, Issue 3. Elsevier, Oxford 1996.

21. Ševelová L, Vachek J. Decontamination efficacy of DESPRACH preparation from stocked supplies of IPB type 80. Zprav Voj Farm 2003:13:9-12 (in Czech).
22. Van Hooidonk C, Brebart-Hansen JCAE.Stereospecific reaction of isopropyl methylphosphonofluoridate (sarin) with $\alpha$-cyclodextrin. Rec Trav Chim Pays-Bas 1970;89:289-99.

23. Weil CS. Tables for convenient calculation of median-effective dose $\left[\operatorname{LD}_{50}\right.$ or $\mathrm{ED}_{50}$ ] and instructions in their use. Biometrics 1952;8:249-63.

24. Zajtchuk R, Bellamy RF. Medical aspects of chemical and biological warfare Office of the Surgeon General, Department of the Army, United states of America, 1997

25. Zhu W, Wu F, Raushel FM, Vigh G. Capillary electrophoretic separation of the enantiomers of organophosphates with a phosphorus stereogenic center using the sodium salt of octakis(2,3-diacetyl-6-sulfo)-gamma-cyclodextrin as resolving agent. J Chrom A 2000;89:247-54.

Submitted January 2004.

Accepted March 2004.

Ing. Kamil Kuča,

Purkyně Military Medical Academy,

Department of Toxicology,

Třebešská 1575, 50001 Hradec Králové,

Czech Republic.

e-mail: kucakam@pmfhk.cz 